\title{
Modeling Black Rhinoceros (Diceros bicornis) Population Performance in East Africa: The Case of Lake Nakuru National Park, Kenya
}

\author{
Geofrey E Soka ${ }^{1 *}$, Alfan A Rija ${ }^{1}$ and Alfred Owino ${ }^{2}$ \\ ${ }^{1}$ Department of Wildlife Management, Sokoine University of Agriculture, Tanzania \\ ${ }^{2}$ National Museums of Kenya, PO Box 40658, Nairobi, Kenya
}

"Corresponding author: Geofrey E Soka, Department of Wildlife Management, Sokoine University of Agriculture, Tanzania, Tel: 255782975720; E-mail: gesoka@gmail.com

Rec date: Mar 21, 2014; Acc date: Apr 24, 2014; Pub date: May 4, 2014

Copyright: (c) 2014 Soka GE, et al. This is an open-access article distributed under the terms of the Creative Commons Attribution License, which permits unrestricted use, distribution, and reproduction in any medium, provided the original author and source are credited.

\begin{abstract}
The black rhinoceros have declined across Africa both in numbers and range distribution, making long-term population persistence of this iconic species uncertain. We conducted simulation models to predict population performance of black rhinoceros in Lake Nakuru National Park under different scenarios of environmental variation and translocation regimes. A decade-long (1987-1997) demographic data were used to construct stochastic simulation models using VORTEX computer program. In addition, we assessed extinction risks and patterns of heterozygosity among the modelled populations (reported every five years) to characterize the dynamics of this population over a hundred years. The population of black rhinoceros showed varying patterns of fluctuations under different scenarios. The best-case scenario showed a considerable increase in the modelled population with the population attaining the highest growth (population growth $(\lambda)=1.04$ ) after 40 years. The mean final population size for the successful cases was $70.85 \pm 2.0$ animals, which was relatively close to the carrying capacity used in the simulation. The expected heterozygosity was $0.912 \pm 0.02$ suggesting that the remaining population may be genetically viable. Further, environmental variation of $1-2 \%$ magnitude across the various age categories, and without translocation, had no significant effect on the deterministic growth rate of the population. Maintaining the translocation of 2 males and 2 females on yearly basis would significantly boost and sustain the population of black rhinoceros in the study area.
\end{abstract}

Keywords: Black rhinoceros; Extinction risks; Harvest; Modeling; Population viability; Lake Nakuru; Kenya

\section{Introduction}

Large mammal populations across Africa have faced considerable reduction in numbers due to natural and human-induced causes [1-4]. Habitat loss due to deforestation [4], agricultural farming, and encroachment [5-7] have been a common concern in most protected and non-protected areas inhabited by wild animals. Collectively, these threats have led to the reduction of the natural range in most species [3]. Range contraction has particularly been more severe among species with large home ranges due to the blockage of movement corridors leading to population isolation $[8,9]$. Further, illegal trade in wildlife trophies from iconic species such as rhinoceros and elephant has dramatically increased, leading to a severe reduction in these species' populations [10]. The black rhinoceros have suffered a drastic decline in the total numbers and range distribution since the last few decades; and between 1970 and 1992, its population had decreased from 65,000 to 2,300 in the wild [11-13]. The major cause of the drastic decline over that period has been attributed mainly to poaching $[11,14,15]$.

However since 1996, there have been increased anti-poaching efforts, and with some encouraging results resulting into population recovery $[13,16]$. Nevertheless, poaching continues to be the major cause of black rhinoceros population decline [16-18]. Kenya's efforts to protect and recover black rhinoceros population began in the mid-1980s, after years of poaching that led to the collapse of the national black rhino population from 20,000 in 1970 to just 400 animals by 1983 [19]. A national Save the Black Rhino Programme was initiated, and the species was given special protection status in the country [20]. As part of this effort, rhinoceros Sanctuary was established in starting with a core population of 18 individuals (7 females and 11 males) [19]. Additionally, to conserve black rhinoceros in Kenya, the wildlife management authority, (Kenya Wildlife Service) adopted a new management plan for rhinoceros conservation in the country [8]. The broad goals of the strategy were to enhance rapid black rhinoceros population recovery through increased attention to biological management and law enforcement [20]. The objective of the strategy was to increase the number of black rhino by at least $5 \%$ per annum, and reach a total of 500 rhinos by 2005,650 rhinos by 2010 and 1000 rhinos by 2020 [19]. Consequently, the Rhino Programme of Kenya Wildlife Service initiated a consistent monitoring of the black rhinoceros populations in the country providing information for improving the conservation of threatened populations. Monitoring involved collecting demographic data (density, births, deaths, translocation, and sex and age structure) that could be used to improve conservation management of this species in the area [20]. Moreover, elsewhere a number of factors have been observed to have had an influence on the dynamics of the black rhinoceros population. These factors range from habitat limitations due to competition for available browse resources [21], natural mortality and predation [22,23], poaching [10] to environmental stress due to climate change impacts [23-25]. Collectively, these factors may impose an additive negative effect on the vital rates of the black rhino population, and thereby 
Page 2 of 6

increasing further its population dynamics. In the present study, we aimed at examining how the set targets of the program could be achieved over the course of the proposed time and beyond. We asked ourselves how many individuals could be translocated from the park to other sites and what would be the appropriate harvest/removal time interval that could maintain the remaining black rhinoceros population in the area? Elsewhere, population viability studies have been useful in assessing the impacts of human exploitation and management efforts on the viability of ungulate populations thereby providing information for improving conservation of threatened populations [13,26-29]. In this study, we used a 10 -year population monitoring data (1987-1997) for the black rhinoceros in Kenya, to conduct stochastic simulation models to assess the most likely impacts on the performance of black rhino population at different scenarios of environmental variations (EV) and harvest/translocation regimes. This study provides important information that could be used to improve species conservation in the area.

\section{Material and Methods}

\section{Study site description}

Lake Nakuru National Park $\left(0^{\circ} 22^{\prime} \mathrm{S}, 36^{\circ} 05^{\prime} \mathrm{E}\right)$ is in Kenya's southern Rift Valley. The Park covers an area of about 90 square miles and is the only fenced park in Kenya [19]. The vegetation types consist of grassland, acacia woodland, scrub woodland and vegetation characteristic of saline water ecosystems [30]. The park is a major sanctuary for the black rhinoceros and the Square-lipped white rhinoceros (Ceratotherium simum), the latter was introduced from South Africa [19]. The park also hosts other mammal species and is a major site for flamingo in Kenya [30]. We obtained a decade-long data for the black rhinoceros population for Lake Nakuru National Park from the Rhino Programme of Kenya Wildlife Service. We used the data to construct a life-table that was used in the simulation models for this study.

\begin{tabular}{|l|l|}
\hline Parameter & Value used \\
\hline Age at first reproduction for female $(\mathrm{yr})$ & 7 \\
\hline Age at first reproduction for male (yr) & 8 \\
\hline Mating system & Polygynous \\
\hline Number of young & 1 \\
\hline Female in breeding pool (\%) & 17.8 \\
\hline Sex ratio of young & 0.5 \\
\hline Carrying capacity & 71 \\
\hline Male in breeding pool (\%) & 91 \\
\hline Maximum age (yr) & 50 \\
\hline Simulation time (yr) & 100 \\
\hline Number of iterations & 100 \\
\hline
\end{tabular}

Table 1: Parameters used in the simulation models for the black rhino population in the study area

\section{Life-table generation}

We used the actual age from the youngest ( 1 year) to the oldest (26 years) and scored each of the 18 individuals to age classes from when it was introduced or born to the period over which it was monitored between 1987 and 1997. Our scores were one (1) for the presence of an individual in a particular age class, and zero (0) if an individual died during the monitoring period. The scores within each age class were summed to obtain the total scores for each age class during the tracking period. We pooled age classes into three distinct groups of juveniles (1-4 years), sub-adults (4-8 years) and adults (8-50 years). From the three distinct groups, we calculated survival rates and used a crude birth rate of 0.089 (calculated from the raw data using the total breeding females and the average number of possible infants each breeding female was able to produce over the ten-year period). The calculated survival rates and crude birth rate were used to produce a life table for three age groups; juveniles, sub-adults, and adults.

\begin{tabular}{|c|c|c|}
\hline Age class & Survival rate (Sx) & Reproductive rate (fx) \\
\hline $1-4$ & 0.957 & 0 \\
\hline $4-8$ & 0.976 & 0.087 \\
\hline $8-50$ & 0.986 & 0.088 \\
\hline
\end{tabular}

Table 2: Reproductive, survival and mortality rates for the black rhino population in the study area

\section{Model simulation}

Simulations were conducted using VORTEX (Ver. 7). The life-table information which was used in the simulations is shown in Table 1. The simulations were assumed to be under density independence and no inbreeding could occur because of a relatively large number of animals in the park. The carrying capacity was estimated based on the available resources (i.e. food, habitat and water) that can sustain the maximum population size of black rhinoceros in the study area.

We computed the reproductive, survival, and mortality rates by age classes (Table 2) which were used in the simulation models. We performed six simulations under different scenarios to assess the performance of black rhinoceros population, and with respect to the best case scenario of no environmental variation and harvesting / translocation (Table 3).

\section{Results}

The population performance of black rhinoceros showed varying fluctuating patterns under different scenarios. For the best-case scenario (Scenario 1), the pattern showed a considerable increase in population (Figure 1). The population achieved stable growth $(\lambda)$ of 1.04 after 40 years in 100 years of simulation. The generation times for males and females were equal (26.7 years). The mean final population size for successful cases was $70.85 \pm 2.0$, which was close to the carrying capacity used in the simulation. The expected heterozygosity was $0.91 \pm 0.02$. 
Citation: Soka GE, Rija AA and Owino A et al. (2014) Modeling Black Rhinoceros (Diceros bicornis) Population Performance in East Africa: The Case of Lake Nakuru National Park, Kenya . J Biodivers Endanger Species 2: 126. doi:10.4172/2332-2543.1000126

Page 3 of 6

\begin{tabular}{|c|l|l|l|l|l|l|}
\hline Scenario \# & $\begin{array}{c}\text { Adult f/breeding } \\
\text { rate (\%) }\end{array}$ & \multicolumn{4}{|c|}{ Age mortality rate (mean \pm SD) } & Harvest/translocation regime \\
\hline & & $0-1 \mathrm{yr}$ & $1-4 \mathrm{yr}$ & $4-8 \mathrm{yr}$ & $8-50 \mathrm{yr}$ & $(\mathrm{M} / \mathrm{F}$ ratio) \\
\hline 1 & 0 & $4.3 \pm 0.0$ & $2.4 \pm 0.0$ & $1.4 \pm 0.0$ & $1.4 \pm 0.0$ & 0 \\
\hline 2 & 2 & $4.3 \pm 2.0$ & $2.4 \pm 2.0$ & $1.4 \pm 2.0$ & $1.4 \pm 2.0$ & 0 \\
\hline 3 & 1 & $4.3 \pm 1.0$ & $2.4 \pm 1.0$ & $1.4 \pm 1.0$ & $1.4 \pm 1.0$ & 0 \\
\hline 4 & 1 & $4.3 \pm 1.0$ & $2.4 \pm 1.0$ & $1.4 \pm 1.0$ & $1.4 \pm 1.0$ & 2,2 (on yearly basis) \\
\hline 5 & 1 & $4.3 \pm 1.0$ & $2.4 \pm 1.0$ & $1.4 \pm 1.0$ & $1.4 \pm 1.0$ & 2,2 (after every five years) \\
\hline 6 & 1 & $4.3 \pm 1.0$ & $2.4 \pm 1.0$ & $1.4 \pm 1.0$ & $1.4 \pm 1.0$ & 1,1 (after every four years) \\
\hline
\end{tabular}

Table 3: Environmental variation $(\% \mathrm{EV})$ in adult females breeding and mortality rates across various age classes used in the simulation models for the black rhinoceros population.

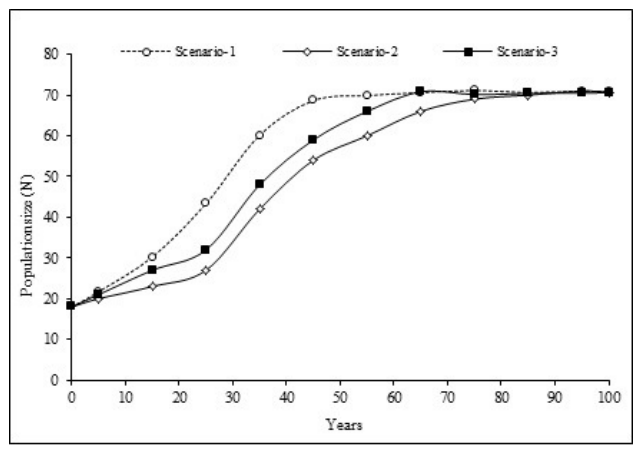

Figure 1: The performance of black rhinoceros population without environmental variation (scenario 1) and with environmental variation of $2 \%$ (scenario 2 ) and $1 \%$ (scenario 3 ).

The introduction of environmental variation of $1-2 \%$ in all the age categories, without harvest (scenarios 2 and 3) showed no difference with the deterministic growth rate observed in the first scenario of growth $(\lambda)$ of 1.04 . Probability of survival for each age-class was also not different. However, a $2 \% \mathrm{EV}$ (scenario 2) reached the carrying capacity after 75 years, as opposed to 65 years at $1 \% \mathrm{EV}$ in scenario 3 (Figure 1). In addition, the mean final population sizes for successful cases were 70.7 and 70.6 for scenarios 2 and 3 respectively; however, the expected heterozygosity was similar (heterozygosity $=0.912$ ) for the two scenarios. Further, the response of black rhinoceros population under harvesting/translocation regimes was highly dynamic over the 100 simulations. The harvesting of 2 males and 2 females on yearly basis showed a mean growth rate of 0.035 in the first five years, but the population declined considerably before becoming extinct after 45 years (Figure 2). The probability of survival for each age-class also showed a similar pattern (Figure 3).

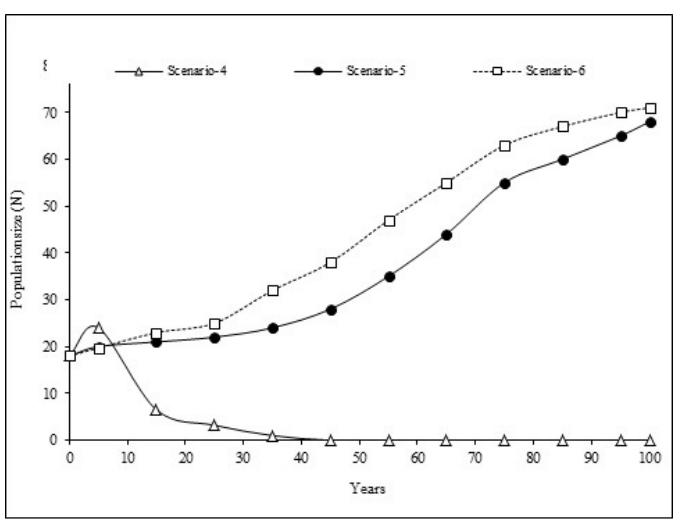

Figure 2: The performance of black rhinoceros population with environmental variation of $1 \%$ and harvesting of 2 males and 2 females on yearly basis (scenario 4), 2 males and 2 females after every five years (scenario 5), and 1 male and 1 female every four years (scenario 6). 
Page 4 of 6

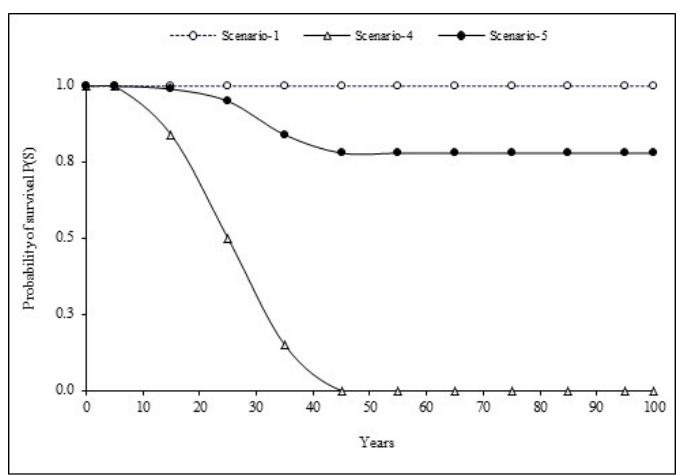

Figure 3: The probabilities of survival of black rhinoceros population without environmental variation (scenario 1) and $1 \%$ environmental variation with the harvest of 2 males and 2 females on yearly basis (scenario 4), and 2 males and 2 females after every five years (scenario 5).

Furthermore, the population remained fairly stable at year 35 when harvest involved 2 males and 2 females every five years (scenario 5). Across all the years, prior to the carrying capacity truncation, the mean growth rate $(\mathrm{r})$ was $0.02 \pm 0.07$, and the population reached its carrying capacity after 100 years (Figure 2). The probability of survival declined but stabilized at 0.8 after 45 years (Figure 3 ). The expected heterozygosity under scenario 5 was $0.85 \pm 0.07$ (Figure 4 ). The mean final population size for the successful cases was $67.41 \pm 10.82$.

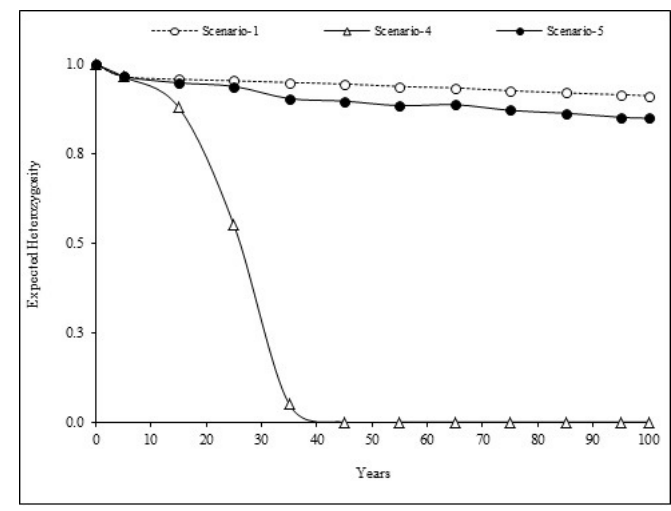

Figure 4: The expected heterozygosity of black rhinoceros population without environmental variation (scenario 1) and 1\% environmental variation with harvest of 2 males and 2 females on yearly basis (scenario 4 ), and 2 males and 2 females after every five years (scenario 5).

The harvesting scenario of 1 male and 1 female every four year with the first harvest in the eighth year led to a fairly stable population and which increased gradually after 25 years before reaching at a carrying capacity in year 95 (Figure 2). Across all the years, prior to carrying capacity truncation, the mean growth rate $(r)$ was $0.02 \pm 0.06$ with the expected heterozygosity of $0.86 \pm 0.01$ in the population.

\section{Discussion}

The general pattern of an increase in black rhinoceros population under initial simulations parameters is not surprising. This is particularly so given the level of protection (fenced park) and adequate security to keep off potential threats such as poaching that has resulted into population decline in eastern Africa. Under the best-case scenario without environmental variation and harvesting, the simulated population showed a steady increase with the mean final population size hovering just below the carrying capacity. This may suggest that the park may be maintained as an appropriate stocking site for the potential re-introduction to other sites in Kenya. In order to achieve this goal however, the managers would be required to institute a more effective management program which targets on managing the habitats and other wild ungulate populations in the area. Several factors have been observed to be playing a regulatory role in the black rhinoceros population elsewhere. As Hrabar and du Toit [24] indicate, the black rhinoceros population in the Pilanesberg National Park was resource limited due to observed signs of density-dependency effect. Further, the authors show that rainfall variability greatly influenced the inter-calving interval and the number of male calves born while increasing the percentage of reproductive cows to a certain density levels. In other areas, studies indicate that resource availability fluctuates with the level and seasonality of rainfall, thereby influencing population dynamics of wild ungulates [25,31]. Furthermore, in Hluhluwe-iMfolozi Park in South Africa, the analysis of a 16-year data of rainfall and black rhinoceros reproduction by Berkeley and Linklater [32] indicates that female conception was strongly seasonal and resulted into most cows dropping more male calves than is the case with female calves during the wet season. The extent to which rainfall affects resources availability and reproduction parameters such as influencing progeny sex ratio [24,32] provides important lessons for the Lake Nakuru black rhinoceros population, which is managed as a source population for restocking other areas. Although there is no study that has looked into how the population of black rhinoceros fares with the rainfall in the study area, some evidence from other areas in Kenya increasingly suggests that rainfall variability may predispose the black rhinoceros population to new and emergent environmental threats. Ndeereh and colleagues [33] recorded unusual black rhinoceros mortalities in Ol Jogi Pyramid Sanctuary in Kenya. They associated the incidence with increased environmental stress (extended drought and a consequent heavy rainfall) which triggered the eruption of a deadly bacterial disease (caused by Clostridial perfringens), that caused death to ten black rhinoceros. In our simulated population models, the levels of environmental variability caused by some of the factors explained in these studies indicate great influence on the dynamics of the black rhinoceros population in Lake Nakuru National Park. For example, 2-percent variability in important population parameters resulted into almost 10 years delayed time for the population to reach a carrying capacity. These results suggest that it is important to understand the role of environmental variability on the dynamics of the black rhino population in the study area.

In the lake Nakuru National Park, the study population may be faced with competitive pressures from other animals depending on similar browse resources and may also greatly influence the dynamics of the rhinoceros population. As Landman and Kerley [21] indicate, black rhinoceros population sharing habitats with other browsers (Loxodonta africana) in Addo National Park, South Africa may be limited due to resource competition. Predation and competition for the available resources may affect female fecundity through increasing calf mortality rate and extending inter-calving interval thereby 
determining population growth in black rhinoceros population $[22,23]$. The black rhinoceros population in Lake Nakuru may potentially be constrained by other browsing ungulates (Eland, Tragelaphus oryx and Rothschild's giraffe, Giraffa camelopardalis rothschildi) as well as predation by lion, although, currently, the effects of these species on the study population is not known. Despite this, in our simulation models, we attempted to represent these causes into the models by using different levels $(1,2 \% \mathrm{EV})$ of the effects they may have on important vital rates of the population. The models with 2 $\% \mathrm{EV}$ experienced the highest dynamics of the black rhino population. This finding strongly suggests the necessity for quantifying these parameters in the field particularly during the current era of climate changes where most wildlife populations are projected to face severe population declines [25]. Increased droughts will particularly be more severe in semi-arid and arid regions including our study area and may further decrease the abundance of several wildlife species [34-37].

The pattern of heterozygosity in the modelled population of the black rhinoceros is not warring. In all scenarios (except scenario 4), models showed good levels of heterozygosity (above 0.8 ) suggesting that the study population may not be constrained by genetic bottleneck at least at the present. Our analyses suggest further that this level of heterozygosity could be maintained by a strategy that allows harvesting to occur after every 4-5 years. Annual removal may have negative impacts on the population, as chances of inbreeding could increase among the sub-adults left in the process as only mature adults are translocated at present. Further, although the park set management level of 71 individuals, our simulations showed that the park can be more productive, and supply more individuals for re-introduction to other sites if well-planned harvesting/translocation strategies at different time intervals are implemented. Studies have shown that the inter-calving interval of black rhinoceros varies from 3 to 6 years [16, 38]. In the study area, the percentage of female rhinos that are able to reproduce increased during the monitoring period. Despite this, annual harvesting of equal numbers of females and males was severe for the population viability of this species in the park. The management implication of this is that a longer duration of reaching a carrying capacity (i.e. 71 animals) may be suitable as this would allow both recovery and availability of enough stock for translocation. Furthermore, the population could only attain its carrying capacity when additional mortalities (such as illegal hunting for rhino horns) and diseases have been controlled. Poaching is increasing throughout East Africa affecting rhino populations even in areas currently receiving the highest protection status $[39,40]$. The Lake Nakuru National Park rhino population may not be secure from the widespread rhino poaching occurring in Kenya. The studies conducted elsewhere on the factors and potential threats to the rhinoceros population should provide lessons for the best management options required to sustain the population of black rhinoceros in Lake Nakuru National park and to realize its mission as a source population for restocking other areas in the country. Therefore, investigation on the factors responsible for population dynamics and long-term monitoring of the black rhinoceros population should be a priority in this semi-arid protected area.

\section{Acknowledgements}

We are grateful to all those who provided useful information during the preparation of this manuscript. Our special thanks go to Prof. Peter Ryan of the University of Cape Town for useful comments during data analyses. Dr. Hashim Mohamed and three anonymous reviewers provided comments on the manuscript.

\section{References}

1. Western D, Russell S, Cuthill I (2009) The Status of Wildlife in Protected Areas Compared to Non-Protected Areas of Kenya. PLoS ONE 4: e6140.

2. Craigie ID, Baillie JEM, Balmford A, Carbone C, Collen B, et al. (2010) Large mammal population declines in Africa's protected areas. Biological Conservation 143: 2221-2228.

3. Ogutu JO, Owen-Smith N, Piepho, HP, Said MY (2011) Continuing wildlife population declines and range contraction in the Mara region of Kenya during 1977-2009. Journal of Zoology 285: 99-109.

4. Kideghesho JR, Rija AA, Mwamende KA, Selemani IS (2013) Emerging issues and challenges in conservation of biodiversity in the rangelands of Tanzania. Nature Conservation6: 1-29.

5. Serneels S, Said MY, Lambin EF (2001) Land cover changes around a major east African wildlife reserve: the Mara ecosystem (Kenya). International Journal of Remote Sensing 22: 3397-3420.

6. Thompson M, Homewood K (2002) Entrepreneurs, elites and exclusion in Maasailand: trends in wildlife conservation and pastoralist development. Human Ecology 30: 107-138.

7. Ogutu JO, Piepho HP, Dublin HT, Bhola N, Reid RS (2009)Dynamics of Mara-Serengeti ungulates in relation to land use changes. Jouranl of Zoology (London) 278: 1-14.

8. Newmark WD (1996) Insularization of Tanzanian parks and the local extinction of large mammals. Conservation Biology 10:1549-1556.

9. Bolger DT, Newmark WD, Morrison TA, Doak DF (2008) The need forintegrative approaches to understand and conserve migratory ungulates. Ecology Letters 11:63-77.

10. UNEP, CITES, IUCN, TRAFFIC (2013) Elephants in the Dust- The African Elephant Crisis.A RapidResponse Assessment. United Nations EnvironmentProgramme, GRID-Arendal.

11. IUCN (1996) IUCN Red Data List. IUCN Publication Services Unit, Cambridge, United Kingdom.

12. Walpole MJ, Morgan-Davies M, Milledge M, Bett P, Leader-Williams N (2001) Population dynamics and future conservation of a free-ranging black Rhinoceros (Dicerosbicornis) population in Kenya. Biological Conservation 99: 237-243.

13. Cromsigt J, Hearne J, Heitkonig I, Prins H (2002) Using models in the management of Black Rhino populations. Ecological Modelling149: 203-211.

14. Hutchins M, Kreger MD (2006) Rhinoceros behaviour: implications for captive management and conservation. International Zoo Yearbook40:150-173.

15. Fyumagwa RD, Nyahongo JW (2010) Black Rhino conservation in Tanzania: translocation efforts and further challenges. Pachyderm47: 59-65.

16. Emslie R, Brooks M (1999) African Rhino Status Survey and Conservation Action Plan, IUCN/SSC African Rhino Specialist Group. IUCN, Gland, Switzerland and Cambridge, UK.

17. Morgan-Davies M (1996) Status of the black Rhinoceros in Masai Mara National Reserve, Kenya. Pachyderm21: 38-45.

18. Mills JA (1997) Rhinoceros Horn and Tiger Bone in China: and Investigation of Trade since the 1993 Ban. TRAFFIC International, Cambridge, USA.

19. Wambwa E (2003) Disease and health concerns of black rhino in east Africa. Kenya Wildlife Service, Nairobi, Kenya.

20. Okita-Ouma B, Amin R, van Langevelde F, Leader-Williams N (2009) Density dependence and population dynamics of black Rhinos (Dicerosbicornismichaeli) in Kenya's Rhino sanctuaries. African Journal of Ecology48: 791-799.

21. Landman M, Kerley GI (2014) Elephant both Increase and Decrease Availability of Browse Resources for Black Rhinoceros. Biotropica 46: 42-49. 
Citation: Soka GE, Rija AA and Owino A et al. (2014) Modeling Black Rhinoceros (Diceros bicornis) Population Performance in East Africa: The Case of Lake Nakuru National Park, Kenya . J Biodivers Endanger Species 2: 126. doi:10.4172/2332-2543.1000126

Page 6 of 6

22. Law PR, Fike B, Lent PC (2013) Mortality and female fecundity in an expanding black rhinoceros (Diceros bicornis minor) population. European Journal of Wildlife Research 59: 477-485.

23. Freeman EW, Meyer JM, Bird J, Adendorff J, Schulte BA, et al. (2014) Impacts of environmental pressures on the reproductive physiology of subpopulations of black rhinoceros (Diceros bicornis bicornis) in Addo Elephant National Park, South Africa. Conservation Physiology 2: 1-13.

24. Hrabar H, du Toit JT (2005) Dynamics of a protected black rhino (Diceros bicornis) population: Pilanesberg National Park, South Africa. Animal Conservation 8: 259-267.

25. Duncan C, Chauvenet ALM, McRae LM, Pettorelli N (2012) Predicting the Future Impact of Droughts on Ungulate Populations in Arid and Semi-Arid Environments. PLOS ONE 7: e51490.

26. Heinsohn R, Lacy RC, Lindenmayer DB, Marsh H, Kwan D, et al. (2004). Unsustainable harvest of dugongs in Torres Strait and Cape York (Australia) waters: two case studies using population viability analysis. Animal Conservation 7: 417-425.

27. Marmontel M, Humphrey SR, O'Shea TJ (1997). Population viability analysis of the Florida manatee (Trichechus manatus latirostris), 1976 -1991. Conservation Biology 11: 467-481.

28. Rija AA (2009) The long-term impacts of hunting on the population viability of wild ungulates in Tarangire, Northern Tanzania. M. Sc thesis, Victoria University of Wellington, Wellington, New Zealand.

29. Selier SAJ, Page BR, Vanak AT, Slotow R (2014) Sustainability of elephant hunting across international borders in southern Africa: A case study of the greater Mapungubwe Transfrontier Conservation Area. The Journal of Wildlife Management 78: 122-132.

30. Bennun LA, Njoroge P (1999) Important Bird Areas in Kenya. East Africa Natural History Society, Nairobi, Kenya.

31. Ostfeld RS, Keesing F (2000) Pulsed resources and community dynamics of consumers in terrestrial ecosystems. Trends in Ecology and Evolution 15: 232-237.
32. Berkeley EV, Linklater WL (2010) Annual and Seasonal Rainfall May Influence Progeny Sex Ratio in the Black Rhinoceros. South African Journal of Wildlife Research 40: 53-57.

33. Ndeereh D, Okita-Ouma B, Gaymer J, Mutinda M, Gakuya F (2012) Unusual Mortalities of Eastern Black Rhinoceros (Diceros bicornis michaeli) due to Clostridial Enterotoxaemia in Ol Jogi Pyramid Sanctuary, Kenya. Pachyderm 51: 45-51.

34. Young TP (1994). Natural die-offs of large mammals: Implications for conservation. Conservation Biology 8: 410-418.

35. Loveridge AJ, Hunt JE, Murindagomo F, Macdonald DW (2006) Influence of drought on predation of elephant (Loxodonta africana) calves by lions (Panthera leo) in an African wooded savannah. Journal of Zoology 270: 523-530.

36. Foley C, Pettorelli N, Foley L (2008) Severe drought and calf survival in elephants. Biology Letters 4: 541-544.

37. Augustine DJ (2010) Response of native ungulates to drought in semiarid Kenyan rangeland. African Journal of Ecology 48: 1009-1020.

38. Mills JA, Morkel P, Runyoro V, Amiyo A, Muruthi P, Binamungu T, Borner M, Thirgood S (2003) Management of Black Rhino in the Ngorongoro Crater. A report on the Ngorongoro Black Rhino Workshop.

39. Lindsey PA, Roulet PA, Romanach SS (2007) Economic and conservation significance of the trophy hunting industry in sub-Saharan Africa. Biological Conservation 134: 455-469.

40. Milliken T, Richard HM, Talukdar B (2009) African and Asian Rhinoceroses - Status, Conservation and Trade. A report from the IUCN Species Survival Commission (IUCN/SSC) African and Asian Rhino Specialist Groups and TRAFFIC to the CITES Secretariat pursuant to Resolution Conf. 9.14 (Rev. CoP14) and Decision 14.89. 